DOI: https://doi.org/10.31933/dijdbm.v2i2 Received: 25 September 2020, Revised: 20 December 2020, Publish: 1 March 2021

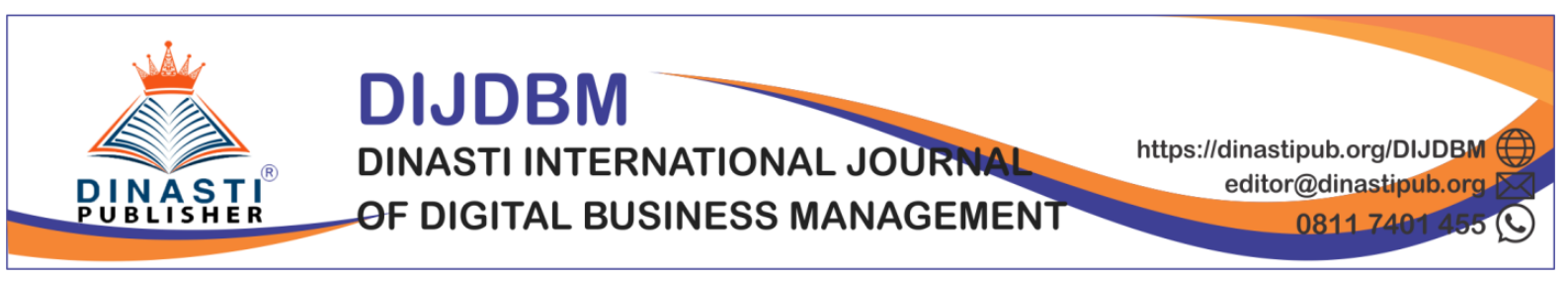

\title{
FORMING CUSTOMER LOYALTY THROUGH FACTORS IN MEDIATION OF CUSTOMER SATISFACTION
}

\author{
Agung Hudaya ${ }^{1)}$ \\ ${ }^{1)}$ Lecturer, Universitas Mercu Buana (UMB), Jakarta Indonesia, agung24@ mercubuana.ac.id
}

Corresponding Author: First Author ${ }^{1}$

\begin{abstract}
The purpose of this study is to determine how price, service quality, customer satisfaction on customer loyalty and how much influence, price, service quality on customer satisfaction which has implications for customer loyalty. The sample used in this study amounted to 100 respondents who were taken by simple random sampling technique. Data analysis in this study used Structural Equation Modeling (SEM) which was carried out with the help of the SEM program from Smart PLS 3.0. Besides, this research also proves that the price variable will affect customer satisfaction, then the price will also affect customer loyalty, as well as service quality affects customer satisfaction and will also affect customer loyalty. and also the mediating variable of customer satisfaction which will affect customer loyalty. Blanja.com in Jakarta.
\end{abstract}

Keyword: Price, service quality, customer satisfaction, customer loyalty.

\section{INTRODUCTION}

Along with the demands of the times and various kinds of routine activities from the community, especially those with careers, of course time is very valuable, especially for people who live in Jakarta, time is very expensive so they make the best use of their time so that everything can run smoothly without disturbing other activities. As a seller, you must understand that in doing business, victory can be achieved by creating satisfaction through product innovation, pricing, and services in accordance with buyer or consumer expectations. Marketing that can be successful is marketing that is oriented towards customer satisfaction which is a necessity to be able to win this competitive competition. If we pay attention to the rapidly growing e-commerce companies every day, there are many things that make it easier for people to access the internet and smartphones, which have now become easily accessible items for everyone. In line with the development of e-commerce, most online stores already have mobile apps that make it easier for consumers to access and view the goods they need that are purchased through these online stores.

In Indonesia, the number of internet users reaches 82 million people or around $30 \%$ of the total population of Indonesia, the e-commerce market is a gold mine for some business people who can see the potential in the future. This development is supported by data from the Minister of Communication and Information which states that the value of e-commerce 
transactions in 2016 reached IDR 349 trillion. This is a very fantastic number considering that only about $7 \%$ of internet users in Indonesia have ever shopped online, according to data from McKinsey.

The value of income from online shopping transactions attracts investors, both domestic and foreign. Several big VCs (Venture Capital) such as Rocket Internet, Cyber Agent, East Ventures, and Ideo Source have even invested in E-commerce companies based in Indonesia, such as Lazada and Zalora, Berry Benka, Toko Pedia, Bilna, Saqina, VIP Plaza, and Blanja.com.

These online shops not only try to always update the features on the website page with the latest technological developments, but also try to attract buyers to buy products provided using the e-marketing strategy.

In Indonesia, the number of internet users reaches 82 million people or around $30 \%$ of the total population of Indonesia, the e-commerce market is a gold mine for some business people who can see the potential in the future. This development is supported by data from the Minister of Communication and Information which states that the value of e-commerce transactions in 2016 reached IDR 349 trillion. This is a very fantastic number considering that only about $7 \%$ of internet users in Indonesia have ever shopped online, according to data from McKinsey.

Compared to China which has reached $30 \%$, Indonesia is still far behind, but we need to remember that this number will continue to increase with the growth of smartphone use, internet penetration in Indonesia, use of debit and credit cards, and the level of consumer confidence in online shopping. In 2012, an e-commerce company in Indonesia recorded $41 \%$ of their sales from Jakarta, but six months later this figure fell to $22 \%$.

Data from research institutes predicts that the e-commerce market in Indonesia will grow 42\% from 2012-2015. This figure is higher when compared to other countries such as Malaysia (14\%), Thailand (22\%), and the Philippines (28\%). The following is data on ecommerce users in Indonesia when compared to neighboring countries in 2012 to 2015. Based on the latest data from Statista, the number of e-Commerce users in Indonesia continues to grow. In 2016, the number of e-Commerce users reached 25.1 million and is predicted to reach 39.3 million in 2020. The following is a graph of the growth of e Commerce users in Indonesia as reported by

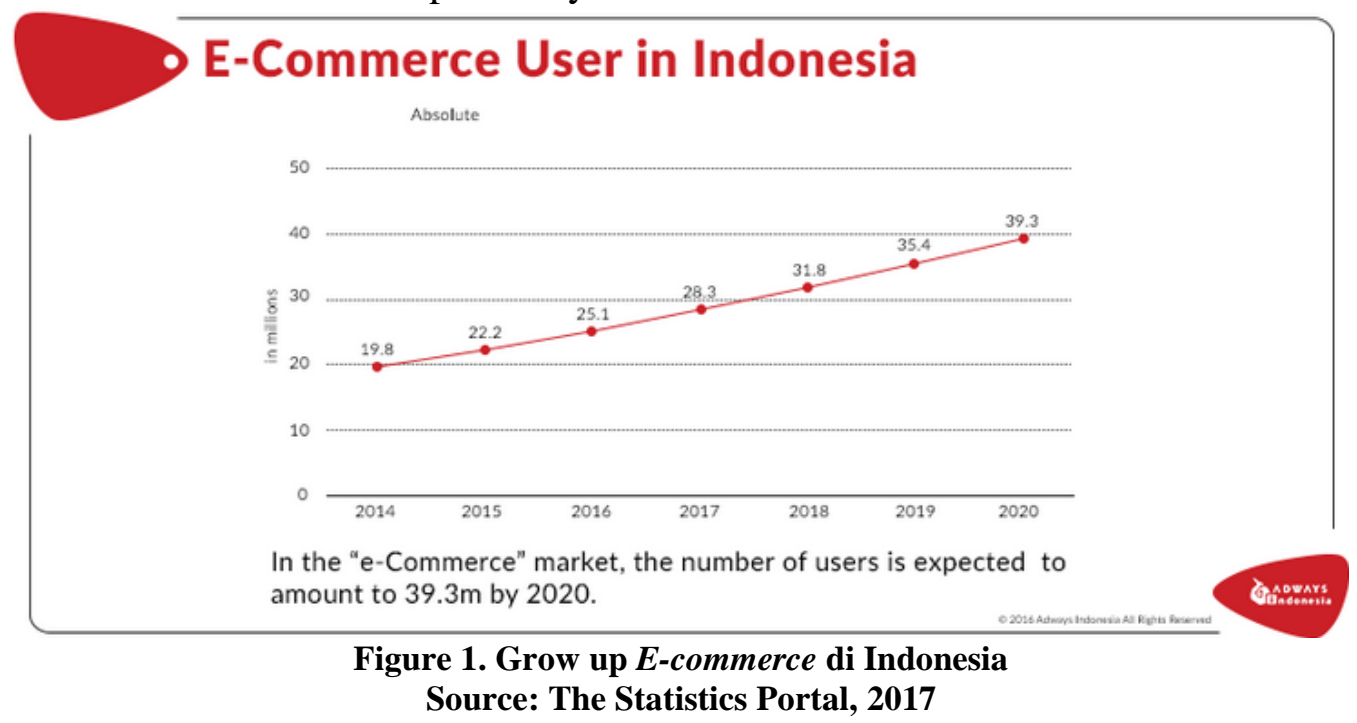


In line with the increasing number of users, revenue from the e-Commerce market from 2014 to 2016 also continues to experience growth and is expected to reach $\$ 16,421$ million in 2020 with the average revenue value per user (ARPU) currently reaching $\$ 418.28$ million.

The graph above shows that the growth of the e-Commerce industry in Indonesia is very fast. The market is expanding and the competition is getting tougher. Each player must compete to win sales. An effective marketing program is certainly very much needed in order to direct consumers to make purchases and generate sales for e-Commerce players.

The results of interviews with 20 (twenty) Blanja.com customer respondents regarding "Customer Satisfaction" are as follows: 11 (eleven) people (55\%) customers stated that they were dissatisfied with Blanja.com due to price problems, because some prices were still more expensive when compared to other online shops. Dissatisfaction was also caused by the product sent that did not match what was displayed on the website, and 9 (nine) people (45\%) expressed satisfaction because customer service was satisfactory.

The results of previous research by Ali, H (2017) that price perceptions affect customer loyalty through customer satisfaction. Yuan (2019) Price is a factor that is taken into account in achieving customer satisfaction, then with satisfaction, customer loyalty will be achieved. Yaqub (2019). Suggested that it affects customer loyalty directly, or indirectly, namely on customer satisfaction, which in turn also affects customer loyalty. Because the research results show that the construct has a significant effect on customer satisfaction and customer loyalty. Lie (2019). The results showed that price has a significant effect on customer satisfaction, then customer satisfaction fully mediates customer loyalty through the construct of price. argued that the effect of price perception affects customer loyalty through customer satisfaction.

In addition, the results of previous research by Ali, H (2017), show that service quality has an effect on customer loyalty through customer satisfaction has a positive and significant effect. Agus, A. (2019). The service perception that is presented has a significant influence on customer satisfaction and then continues to customer loyalty. With good service quality, customer satisfaction will be obtained. Özkan (2019). Customers will find satisfaction through the quality of service provided by the company, the quality of service becomes a benchmark in achieving customer satisfaction. With excellent service quality, customer satisfaction will be achieved. Fitri (2019). This study shows that customer satisfaction affects customer loyalty very well. The company increases the factors that influence customer satisfaction in order to create customer loyalty. Andi, H. (2019). This study shows that conventional mediation between service quality and customer satisfaction is proven true. In this study, specifically discussing the digital world, namely e-marketing in the scope of customer satisfaction and customer loyalty. suggested that the effect of service quality on customer satisfaction.

With the various considerations mentioned above, the researcher wants to do research in the field of e-marketplaces at online shops that offer competitive products. An online marketplace (e-market place) provides links to companies that sell products and services online and attract consumers through the provision of sales services. Some of the leading examples of e-market place shopping sites in Indonesia such as Blanja.com, Bukalapak, Tokopedia, Lazada, and others, the author wants to research further to prove that the features provided can function as a mechanism for a competitive strategy in online stores.

In essence, online media can display and facilitate buyers, for example, consumers can make a decision to buy a product because of the role of Products, Prices and Services 
obtained from online stores. In this case, researching and analyzing the effect of supporting Product, Price and Service strategies in the success of a company engaged in e-commerce by taking studicase Belanja.com.

The choice of Belanja.com is based on the reason that Belanja.com is one of the companies that meets the needs of customers (buyers) and sellers (sellers). The process in Blanja.com, the buyer makes a payment to Blanja.com. by credit, cash, or through the Alfamart store, then Blanja.com pays to the Seller (Seller). The seller (logistic) sends the goods to the buyer. Blanja.com is one of the participating online shops

\section{Identification of problems}

1) Does price perception affect customer satisfaction at Blanja.com in Jakarta?

2) Does service quality affect customer satisfaction at Blanja.com in Jakarta?

3) Does price perception affect customer loyalty Blanja.com in Jakarta?

4) Does service quality affect Blanja.com customer loyalty in Jakarta?

5) Does customer satisfaction affect Blanja.com customer loyalty in Jakarta?

Based on the use of the research formula, the objectives of the research are as follows:

1. To analyze the influence of price perceptions on customer satisfaction at Blanja.com in Jakarta.

2. To analyze the effect of service quality on customer satisfaction Blanja.com in Jakarta.

3. To analyze the effect of price perceptions on customer loyalty Blanja.com in Jakarta.

4. To analyze the effect of price perceptions on customer loyalty Blanja.com in Jakarta.

5. To analyze the effect of customer satisfaction on customer loyalty Blanja.com in Jakarta.

\section{LITERATURE REVIEW Price perception}

The researcher chooses a dimension that is relevant to the selected object of research, Hui-Chun (2014) explains the dimensions of price discounts and menu packages, namely that in addition to price, the main thing is that price discounts are also a consideration for companies in providing prices, as well as menu packages, buy one free. one or a discount, by buying a package you will get a cheaper price, as well as promotional prices, different from package prices, and discounts, promotional prices are related to events that are running at a certain time, for example, a discount given to visitors who is having a birthday, or discounts related to the date of independence, and other discount events.

Hui-Chun (2014), explains the dimensions of product quality that differentiate a product from others, namely:

1) Discount Price (menu package)

2) Promotional pricing

3) Match between price and portion

According to Pasuraman in Budi Istiyanto (2014) there are 5 dimensions of service quality, namely:

1. Reliability, namely the company's ability to provide services as promised accurately and reliably. 
2. Responsivenes or responsiveness is the willingness of the company to help and provide fast service (responsivenes), and precisely with the delivery of clear information.

3. Assurance or assurance, knowledge of courtesy and the ability of company employees to foster customer trust in the company.

4. Empathy, namely giving attention to customers sincerely and individually.

5. Tangibles or physical evidence is the ability to show its existence to external partie

\section{Cutomer Satisfaction}

In the journal Yu-Te Tu et. al (2012) explains that, consumers are said to be satisfied, they will not return previous products in other words to become regular customers, researchers choose the journal because the journal has an object that is relevant to the object chosen by the researcher.

According to Yu-Te Tu et. al (2012) customer satisfaction can be measured through the following dimensions:

1) Do not return to the previous product.

2) Talking positively to others.

3) Buy new products

\section{Customer Loyalty}

According to Griffin (2014) the definition of loyalty as a form of behavior of decision-making units to make purchases continually on the goods / services of a selected company.

defines loyalty as a customer's commitment to deeply re-subscribe or re-purchase selected products / services consistently in the future. Although the influence of the situation and marketing efforts have the potential to cause behavior change.

Loyal customers are important assets for the company while loyal characteristics are important assets for the company. The characteristics of loyal customers, among others, according to Grifin (2014) are as follows:

1. Refer to other people

2. Regularly refilling

3. Showing immunity to competitors' pulls

Customer loyalty according to Kotler and Keller (2013) can be described as follows:

1. Repeat purchase (loyalty to the product)

2. Retention (resistance to negative influences about other companies)

3. Referrals (refer to the total company extension)

\section{Framework}

Based on the research objectives, literature review, previous research and the relationship between variables, the analytical framework in this study is presented in the form of Figure 1. Where the Brand Awareness variable is an independent variable, the Purchase 
Intention variable as the dependent variable and the Buying Decision variable as the intervening variable, or the variable which mediates between the independent variable and the dependent variable.

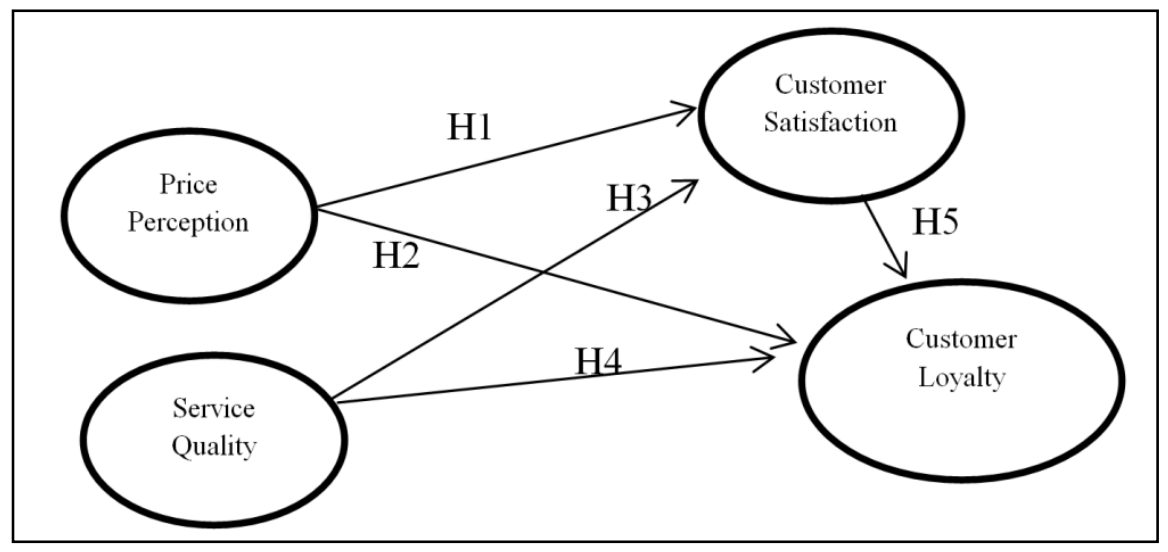

\section{Hypothesis}

Figure 2 Framework

Based on the problem examined, then a hypothesis is drawn as follows:

H1: Price perception affects Customer Satisfaction

$\mathrm{H} 2$ : Service quality affects customer satisfaction

H3: Price perception influences Customer Loyalty

H4: Service quality influences customer loyalty

H5: Customer Satisfaction influences customer loyalty

\section{RESEARCH METHODS}

Model in this study is a model of causality (cause and effect relationship or the influence), then to test the hypothesis used test equipment Structural Equation Model (Structural Equation Modeling - SEM), using PLS 3.0 program. Cutomer Loyalty and Customer Satisfaction as dependent variables, Product Quality and Price Percetion as the dependent variable.

The method can be illustrated as shown in Figure 1 above with the structure and sub structure of the path as below:

$\mathrm{Z}=\mathrm{Pyx} 1 . \mathrm{X} 1+\mathrm{Pyx} 2 . \mathrm{X} 2+\varepsilon 1$

$\mathrm{Y}=\mathrm{Pzx} 1 . \mathrm{X} 1+\mathrm{Pzx} 2 . \mathrm{X} 2+\mathrm{Pzy} . \mathrm{Z}+\varepsilon$

Note: $\mathrm{X} 1=$ Price Perception; $\mathrm{X} 2=$ Service quality $; \mathrm{Z}=$ Customer satisfaction; $\mathrm{Y}=$ Customer Loyalty; and $\mathcal{E}=$ epsilon (other factors that influence)

\section{FINDINGS AND DISCUSSION}

\section{Research result}

There are three values that must be considered at this stage, namely convergent validity, discriminant validity, and composite reliability.Convergent validity, the correlation between the reflexive indicator scores and the latent variable scores. This research uses 
loading 0.5 to 0.6 is considered sufficient, because it is the initial stage of developing the measurement scale and the number of indicators per construct is not large, namely 2 (two) to 4 (four) indicators.Discriminant validity, reflexive indicator measurement based on cross loading with its latent variables. Another method is by comparing the square root of average variance extracted (AVE) values of each construct with the correlation between other constructs in the model. If the initial measurement values of the two methods are better than the other construct values in the model, it can be concluded that the construct has a good discriminant validity value or vice versa. Accordingly, it is recommended that the measurement value be greater than 0.50.Composite reliability, a block indicator that measures the internal consistency of construct indicators, shows the degree to which it indicates common latent (unobserved). The construct is declared reliable if it has a composite reliability value above 0.70 and Cronbach's alpha above 0.60 even though it is not an absolute standard.

\section{Convergent Validity}

Convergent validity is used to determine instrument items that can be used as indicators of overall latent variables. The results of this test are measured based on the value of the loading factor (external loading) of the construction indicator. The following convergent validity test results are presented in the table:

Table 1. Table of Convergent Validity Test Results .

\begin{tabular}{cccc}
\hline Variabel & Indicator & Outer Loadings & Result \\
\hline Price perception & X1.1 & 0.907 & Valid \\
& X1.2 & 0.873 & Valid \\
X1.3 & 0.897 & Valid \\
X1.4 & 0.856 & Valid \\
X1.5 & 0.917 & Valid \\
\hline Service quality & X2.1 & 0.781 & Valid \\
& X2.2 & 0.941 & Valid \\
& X2.3 & 0.882 & Valid \\
& X2.4 & 0.762 & Valid \\
X2.5 & 0.921 & Valid \\
\hline Customer satisfaction & Z1.1 & 0.849 & Valid \\
& Z1.2 & 0.891 & Valid \\
& Z1.3 & 0.868 & Valid \\
& Z1.4 & 0.750 & Valid \\
& Z1.6 & 0.879 & Valid \\
\hline Customer loyalty & Y1.1 & 0.578 & Valid \\
& Y1.2 & 0.895 & Valid \\
& Y1.3 & 0.886 & Valid \\
& Y1.5 & 0.740 & Valid \\
& Yalid \\
& 0.834 & Valid \\
\hline
\end{tabular}

Source: Data processed from Smart PLS output 
The table shows that all outer loading factors have values greater than 0.5 . So that this measurement can be concluded has met the requirements of convergent validity. The convergent validity of the measurement model using reflective indicators is assessed based on the outer loading factor of the indicators that measure the construct. In this study there are 5 constructs with a number of indicators ranging from 3 to 10 indicators with a scale of 1 to 5 . If the correlation coefficient is equal to 0.3 or more (at least 0.3 ) then the instrument is declared valid, and invalid if the correlation coefficient is smaller than 0.3 (Sugiyono, 2016) states based on the results of the loading factors above, it is concluded that the construct which has a dominant loading factor above 0.5 has a good convergent validity.

Validity test is also performed by testing the method of comparing the value of the square root of average variance extracted (AVE) in each construct with the correlation between other constructs contained in the model.

Table 2 . Testing Results Table AVE

\begin{tabular}{lc}
\hline \multicolumn{1}{c}{ VARIABEL } & $\begin{array}{c}\text { Average Variance } \\
\text { Extracted (AVE) }\end{array}$ \\
\hline Price perception & 0.792 \\
Service quality & 0.741 \\
Customer satisfaction & 0.656 \\
Customer loyalty & 0.661 \\
\hline
\end{tabular}

Source: Data processed from Smart PLS output

Composite Reliability and Cron bach's Alpha

In addition to the construct validity test, the construct reliability test is also measured by the composite reliability and Cronbach's alpha of the indicator block that measures the construct. Following are the results of reliability testing and Cronbach alpha composites from

Smart PLS:

Table 3 . Composite Reliability and Cron bach's Alpha tables

\begin{tabular}{ccc}
\hline & Cronbach's Alpha & Composite Reliability \\
\hline Price perception & 0.934 & 0.950 \\
Service quality & 0.911 & 0.934 \\
Customer satisfaction & 0.890 & 0.918 \\
Customer loyalty & 0.895 & 0.918 \\
\hline \multicolumn{2}{c}{ Source: Data processed from Smart PLS output }
\end{tabular}

This construct is stated to be reliable if it has a composite reliability value above 0.70 and Cronbach's alpha above 0.60. From the Smart PLS output above all construction has a composite reliability value above 0.70 .

The measurement model for the validity and reliability test, the coefficient of determination of the model and the path coefficient for the equation model, can be seen in the following figure: 


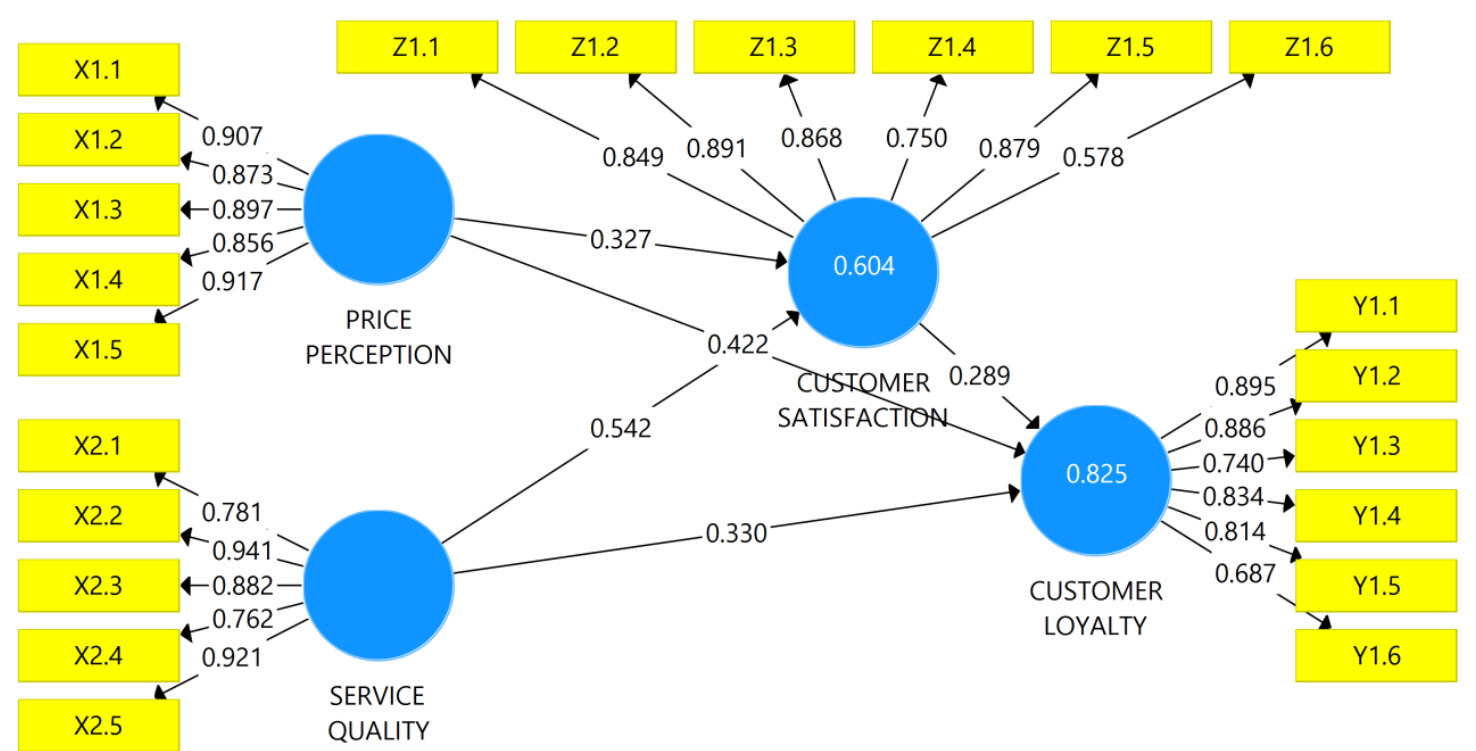

Figure 2. PLS Algorithm

Source: Data processed from Smart PLS output

\section{Structural Model Testing (Inner Model)}

The structural model in PLS is evaluated using R2 for the dependent variable and the path coefficient for the independent variables then the significance is assessed based on the $\mathrm{t}$ statistic value of each path. The structural model of this research can be seen in the following figure:

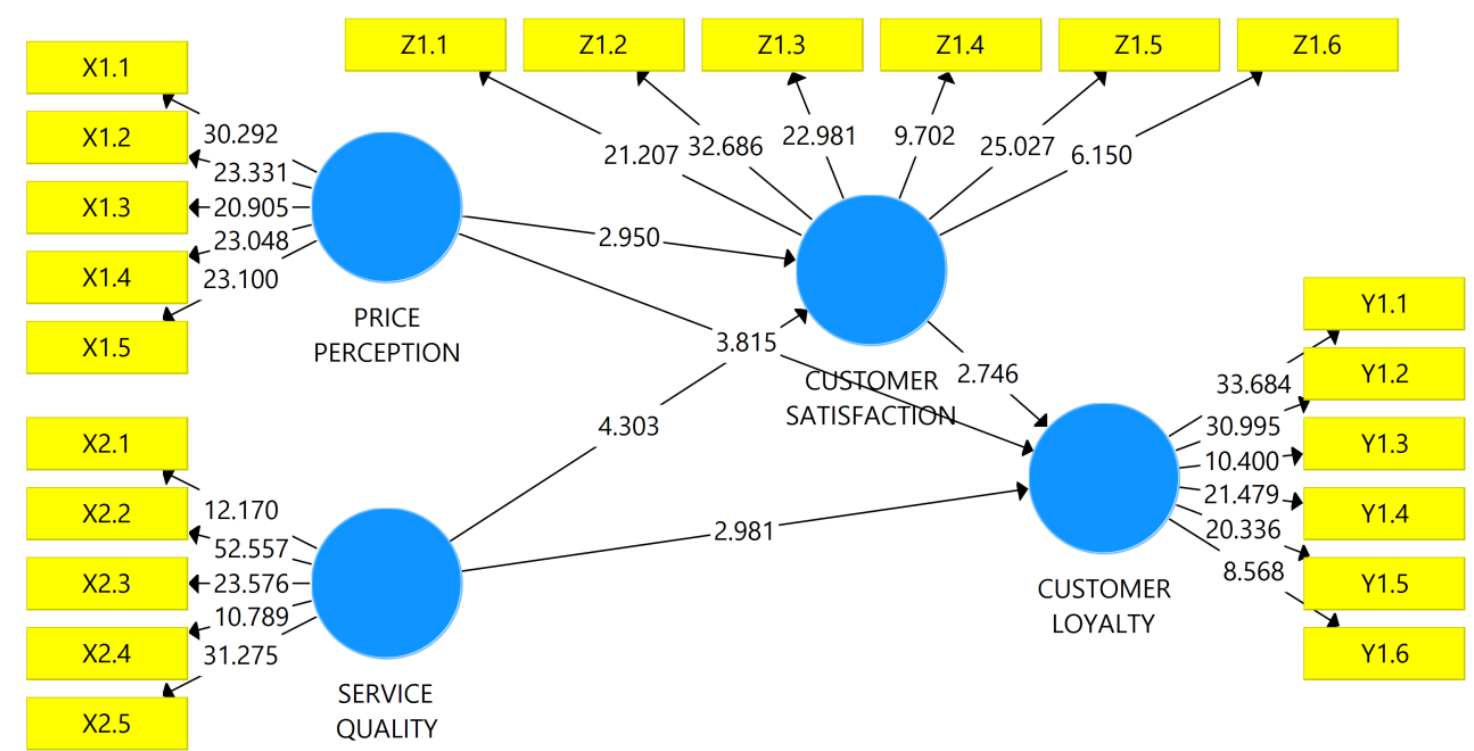

Figure 3. Display of PLS Bootstrapping Results

Source: Data processed from Smart PLS output

$\mathrm{R} 2$ values for each endogenous variable in this study can be seen in Table 
Table 4. R-Square table

\begin{tabular}{lcc}
\hline Variabel & $\boldsymbol{R}$ Square & $\begin{array}{c}\boldsymbol{R} \text { Square } \\
\text { Adjusted }\end{array}$ \\
\hline Customer satisfaction (Z) & 0.604 & 0.596 \\
Customer loyalty (Y) & 0.825 & 0.820 \\
\hline \multicolumn{2}{r}{ Source: Data processed from Smart PLS output }
\end{tabular}

R Square Value of Customer satisfaction (Z) of 0.604 shows a double correlation (price perception and service quality). And R Square Customer loyalty Value (Y) of 0.825 shows a double correlation (price perception, service quality and customer satisfaction)

\section{Goodness of Fit}

In the next stage the model evaluation will be carried out through goodness of fit. Goodness of fit assessment is known from the Q-Square value. Q-Square value has the same meaning as the coefficient of determination (R-Square) in the regression analysis, where the higher the Q-Square, the model can be said to be more suitable with the data. The results of calculating the Q-Square values are as follows:

$$
\begin{aligned}
\text { Q-Square } & =1-[(1-0,604) \times(1-0,825)] \\
& =1-(0,396 \times 0,175) \\
& =1-0,221 \\
& =0.779
\end{aligned}
$$

Based on the calculation above, the Q-Square value of 0.779 is obtained. This shows the amount of diversity of research data that can be explained by the research model is $77.9 \%$, while the remaining $22.1 \%$ is explained by other factors that are outside this research model. Based on these results, the model in this study can be stated to have had an excellent goodness of fit.

Table 5 . Path Coefficients table (Mean, STDEV, t-Value)

\begin{tabular}{lcccc}
\hline \multicolumn{1}{c}{ Variabel } & $\begin{array}{c}\text { Original } \\
\text { Sample }(\boldsymbol{O})\end{array}$ & T Statistics & P Values & Significance Level \\
\hline Price perception -> Customer satisfaction & 0.327 & 2.950 & 0.000 & $<0.05$ \\
Service quality -> Customer satisfaction & 0.542 & 4.303 & 0.003 & $<0.05$ \\
Price perception -> Customer loyalty & 0.422 & 3.815 & 0.003 & $<0.05$ \\
Service quality -> Customer loyalty & 0.330 & 2.951 & 0.000 & $<0.05$ \\
Customer satisfaction -> Customer loyalty & 0.289 & 2.746 & 0.000 & $<0.05$ \\
\hline
\end{tabular}

Source: Data processed from Smart PLS output

Based on the table above it can be seen that the measurement model formed is the Equation

Model as below:

$$
\begin{aligned}
& Z=0.327 X 1+0.542 X 2 \\
& Y=0.422 X 1+0.330 X 2+0.289 Z \\
& \text { Where, }
\end{aligned}
$$

$\mathrm{X} 1=$ Price perception 
$\mathrm{X} 2=$ Service quality

$\mathrm{Z}=$ Customer satisfaction

$\mathrm{Y}=$ Customer loyalty

The equation above can be interpreted as follows:

1. Price perception Variables have a positive coefficient direction on Customer satisfaction

2. Service quality Variables have a positive coefficient direction on Customer satisfaction

3. Price perception Variable has a positive direction coefficient on Customer loyalty

4. Service quality Variables have a positive coefficient direction on Customer loyalty

5. The Customer satisfaction Variable has a positive direction coefficient on Customer loyalty

\section{Hypothesis testing}

\section{1) The Influence of price perception on customer satisfaction}

The first hypothesis which states that product quality Influences customer satisfaction can be proven true. This can be seen from the statistical $t$ value of 4,143 which is greater than the value of $\mathrm{t}$ table $=1.96$, and a probability value of 0,000 which is smaller than the specified critical value limit of 0.05 . Thus it is stated that product quality has significant and significant effect on customer satisfaction.

The relationship between price perceptions and consumer satisfaction can be caused by indicators and dimensions of price perceptions. Where is the perceived price level of the object under study or in other words the object under study in this case is the effect of perceived price on customer satisfaction. In Ali, H (2016) Customer Satisfaction Model, Yunita, D., Ali, H. (2017) Purchasing Decision Model (Rental) Generator Set: Analysis of Product Quality, Price and Services at PT. Hartekprima Listrindo. Limakrisna, N., Ali, H. (2016). Customer satisfaction model: empirical study on fast food restaurants in Bandung. Agussalim, M., Ali, H. (2017)

\section{2) The Influence of service quality on customer satisfaction}

The second hypothesis which states that service quality Influences customer satisfaction can be proven true. This can be seen from the statistical $t$ value of 4.303 which is greater than the value of $t$ table $=1.96$, and the probability value of 0.003 which is smaller than the specified critical value limit of 0.05 . Thus it is stated that service quality has significant and significant influence on customer satisfaction.

Service quality is proven to have an effect on customer satisfaction. This suggests that good service quality will have a dominant impact on customer satisfaction. Sulistiorini, MS., Ali, H. (2017). Customer Satisfaction Model: Product Analysis, Price, Promotion and Distribution (Case Study at Pt Integrasia Utama). Konuk, F. A. (2019). The Effect of Perceptions of Food Quality, Price Fairness, Perceptions of Value and Satisfaction on Return Visits and Word-of-Mouth Intention on Organic Food Restaurants El-Adly, M.I. (2019) Ikhsani, K., Ali, H. (2017). 


\section{3) The Influence of price perception on customer loyalty}

The third hypothesis which states that price perception influences the customer loyalty can be proven true. This can be seen from the statistical $t$ value of 3.815 which is greater than the value of $t$ table $=1.96$, and the probability value of 0.003 which is smaller than the specified critical value limit of 0.05 . Thus it is stated that the price perception has significant influence on the customer loyalty.

Price perception variable with consumer loyalty has a strong relationship value. The strong influence of dimensions and indicators formed from price perception on consumer loyalty is in line with the research of Djumarno, S.O., \& Djamaludin, S. (2017): The Effect of Brand Image, Product Quality, and Relationship Marketing on Customer Satisfaction and Loyalty. Djumarno, S. A., \& Djamaluddin, S. (2018). The Effect of Product Quality and Price on Customer Loyalty through Customer Satisfaction. Alafityanto, A., \& Djumarno, D. The Effect of Product Quality, Product Price and Distribution on Customer Satisfaction and Its Effect on Customer Loyalty

\section{4) The Influence of service quality on customer loyalty}

The fourth hypothesis which states that service quality Influences customer loyalty can be proven true. This can be seen from the statistical $t$ value of 2.951 which is greater than the value of $t$ table $=1.96$, and the probability value of 0.000 which is smaller than the specified critical value limit of 0.05 . Thus it is stated that price perception has significant and significant influence on customer loyalty.

There is a correlation in this research between service quality variables on customer loyalty which states that increasing will have an impact on purchasing decisions that are also high in accordance with research Turuis, T. F. (2019). Analisis Faktor-Faktor Yang Mempengaruhi Loyalitas Nasabah Tabungan Bunaken

Bergel, M., \& Brock, C. (2019). Visitors' loyalty and price perceptions: the role of customer engagement. Rohwiyati, R., \& Praptiestrini, P. (2019). The Effect of Shopee eService Quality and Price Perception on Repurchase Intention: Customer Satisfaction as Mediation Variable

\section{5) The Influence of customer satisfaction on customer loyalty}

The hypothesis which states that the customer satisfaction influences the customer loyalty can be proven true. This can be seen from the statistical $t$ value of 2.746 which is greater than the value of t table $=1.96$, and the probability value of 0.000 which is smaller than the specified critical value limit of 0.05 . Thus it is stated that the customer satisfaction has significant influence on the customer loyalty.

Variable purchase intention with a purchase decision has a strong enough relationship value. Xie, Y. (2020). The relationship among marketing mix, customer satisfaction and customer loyalty of Chinese tourists to budget hotel of central Bangkok. El-Adly, M. I. (2019). Modelling the relationship between hotel perceived value, customer satisfaction, and customer loyalty. Turuis, T. F. (2019). Cheng, B. L., Gan, C. C., Imrie, B. C., \& Mansori, S. 
(2019). Service recovery, customer satisfaction and customer loyalty. Ely, R. (2019). The effect of product quality to the customer satisfaction and customer loyalty on the local food

\section{CONCLUSION AND SUGESTION}

Based on the discussion in the previous chapter, the results of this study can be concluded as follows:

1. price perception affects consumer satisfaction. In this study, it can be seen that the price perception has a positive coefficient on consumer satisfaction. Apart from the uniqueness of the different prices in each variant studied, this is also due to the characteristics of the respondents in this study in different circles causing the perception of prices to vary. The perception dimension of hatga has a strong relationship, this is supported by varying prices. By adjusting to consumer desires, the appropriate price will refer to the right consumer. Most of the characteristics of consumers in this study are lower middle consumers, where consumers in these characteristics tend to show a desire for products that meet their expectations, especially at low prices.

2. Service quality has a significant effect on customer satisfaction. a fairly strong relationship that occurs with customer satisfaction. This provides an illustration of the quality of service which is considered very relevant to the economy of the surrounding community, this is because the cafe sees that those who will buy their products will come from the middle to lower class who tend to pay enough attention to service quality,

3. Price perception affects customer loyalty. In this study, it can be seen that price perception has a positive coefficient on customer loyalty. Apart from the uniqueness of the product under study, this is also due to the characteristics of the respondents in this study with a random system that tends to have unpredictable prices. price perception is inconsistent, price perception is in accordance with each menu offered, will bring customer loyalty, customer loyalty is a situation where they feel comfortable with a situation and they will come or buy back a product again. With the perception of optimal product quality, customer loyalty will arise automatically, customer loyalty in various forms, can buy back a product, or tell good things about a product to others. Therefore customer loyalty in this situation is very important. Because customer loyalty is related to the survival of a company.

4. Service quality has a significant effect on customer loyalty. a pretty strong relationship that occurs with customer loyalty. This gives an idea of that existence. Viewed from the perspective of service quality, certain circles will look excessive and vice versa, low service will look less good in certain circles. By placing the right service for consumers, the quality of service will be a reference for the company to determine the service for each product and service that will be sold by the company. Service quality will affect the loyalty of a consumer, with service quality in accordance with consumer desires will bring the situation into the minds of consumers which will make consumers come repeatedly and buy the same product over and over again.

5. Customer satisfaction has a significant effect on customer loyalty. a pretty strong relationship that occurs with customer loyalty. This existence provides an overview of customer satisfaction which is formed from several factors such as product quality and customer satisfaction. Customer satisfaction must be maintained by paying attention to several factors behind it, many customer satisfaction is not followed by customer loyalty. 
Whereas in the success of a company making repeat purchases is very important for the sustainability of a company. Repeat purchases can be obtained from customer loyalty. Customer satisfaction that is felt repeatedly will lead to customer loyalty, with customer loyalty from consumers in this study being considered good enough. There are many customers who come repeatedly to buy products from the cafe, and there are also many customers who tell good things about the cafe to many people.

\section{Suggestions}

1. Price perceptions in such a marketplace must always pay attention to the price of each product sold, varied and competitive prices will attract a wider range of consumers. Especially in the millennial era where information must continue to be received even in a short time, this is due to avoiding consumer saturation. Customers who are bored with a price that doesn't vary will turn to another platform that they feel will get the price they want.

2. The quality of service offered by the marketplace is quite good, related to the appearance of an attractive site, because consumers feel the right feeling according to the wishes of the target segment. With the right quality of service it will bring in loyal customers, therefore providing quality service is very important.

3. Customer satisfaction will be created by combining perceptions of price and service quality, these two factors will provide customer satisfaction if both can support each other, with product quality that matches the price will create good customer satisfaction, customer satisfaction is a situation where reality is better than with their hopes.

4. Customer loyalty, is a condition where customers will return and will buy back the products they feel, with that loyalty will form optimal customers, these customers will be willing to buy repeatedly and tell good things about the product to many people. people. Loyal customers are the highest level of customer satisfaction, if customer satisfaction has been received then customer loyalty will be expected to come.

\section{REFERENCE}

Agussalim, M., Ali,H. (2017). Model Kepuasan Pelanggan: Analisis Kualitas Produk Dan Kualitas Layanan Terhadap Citra Merek Pada Giant Citra Raya Jakarta. Jurnal Manajemen 21 (3), 317-335.

Alafityanto, A., \& Djumarno, D. (2018) Pengaruh Kualitas Produk, Harga Produk dan Distribusi terhadap Kepuasan Pelanggan Serta Pengaruhnya terhadap Loyalitas Customer (Study pada PT Berri Indosari). Swot, 7(2).

Ali, H., Hadibrata,B., Buchori, CD. (2016). One Stop Services: Quality of Service and Accessibility to

Ali, H., Limakrisna, N., \& Djamalluddin, S. (2016). Model of customer satisfaction: the empirical study at BRI in Jambi. International Journal of Applied Business and Economic Research, 707-719.

Bergel, M., \& Brock, C. (2019). Visitors' loyalty and price perceptions: the role of customer engagement. The Service Industries Journal, 39(7-8), 575-589 
Cheng, B. L., Gan, C. C., Imrie, B. C., \& Mansori, S. (2019). Service recovery, customer satisfaction and customer loyalty: evidence from Malaysia's hotel industry. International Journal of Quality and Service Sciences.

Djumarno, S. A., \& Djamaluddin, S. (2018). Effect of Product Quality and Price on Customer Loyalty through Customer Satisfaction. International Journal of Business and Management Invention (IJBMI), 7(8), 12-20.

Djumarno, S. A., \& Djamaluddin, S. (2018). Effect of Product Quality and Price on Customer Loyalty through Customer Satisfaction. International Journal of Business and Management Invention (IJBMI), 7(8), 12-20.

Djumarno, S. O., \& Djamaludin, S.(2017): The Effect of Brand Image, Product Quality, and Relationship Marketing on Customer Satisfaction and Loyalty. Journal of Business Marketing and Management, 15-24.

El-Adly, M. I. (2019). Modelling the relationship between hotel perceived value, customer satisfaction, and customer loyalty. Journal of Retailing and Consumer Services, 50, 322-332.

Ely, R. (2019). THE EFFECT OF PRODUCT QUALITY TO THE CUSTOMER SATISFACTION AND CUSTOMER LOYALTY ON THE LOCAL FOOD (Case Study in PT ASESE) (Doctoral dissertation, Universitas Andalas).

Ghozali, Imam. (2011). Aplikasi Analisis Multivariate Dengan Program SPSS. Semarang, Edisi 5. BP

Griffin, Ricky W., and Moorhead, Gregory., 2014. Organizational Behavior: Managing People and Organizations. Eleventh Edition. USA: South Western

HUDAYA, A. (2018). ANALISIS FAKTOR YANG MEMPENGARUHI KEPUTUSAN PEMBELIAN (Studi kasus kedai Gerobak Kopi Seruput Jakarta) (Doctoral dissertation, Universitas Mercu Buana Jakarta).

Hui-Chun Huang Ya-Ting Chang Che-Yi Yeh Chung-Wei Liao , 2014, Promote the price promotion. International Journal of Contemporary Hospitality Management, . 26 (7) $1065-1082$

Ikhsani, K., Ali, H. (2017). Keputusan Pembelian: Analisis Kualitas Produk, Harga dan Brand Awareness (Studi Kasus Produk Teh Botol Sosro di Giant Mall Permata Tangerang). Swot 7 (3), 523-541

Konuk, F. A. (2019). The influence of perceived food quality, price fairness, perceived value and satisfaction on customers' revisit and word-of-mouth intentions towards organic food restaurants. Journal of Retailing and Consumer Services, 50, 103110.

Kotler, Philip . (2012). Prinsip-prinsip Pemasaran .Edisi Ketigabelas Jilid I. Erlangga. Jakarta.

Kotler, Philips \& Amstrong, Gary (2012). Prinsip-prinsip Pemasaran Edisi 13, Jilid 1, Jakarta : Erlangga.

Kottler, Philip, Keller, L Kevin (2012). Manajemen Pemasaran. Edisi 12. Jakarta: Erlangga. 
Limakrisna, N., Ali, H. (2016). Model of customer satisfaction: Empirical study at fast food restaurants in bandung. International Journal Of Business And Commerce 5 (6), 132-146.

Nafisa, J., \& Sukresna, I. M. (2018). Analisis Pengaruh Kualitas Layanan, Harapan Kinerja Dan Citra Perusahaan Terhadap Loyalitas Pelanggan Melalui Kepuasan Pelanggan Sebagai Variabel Intervening (Studi Pada Rumah Sakit Islam Sultan Agung Semarang). Diponegoro Journal Of Management, 7(4), 78-104.

Nwachukwu, A., Benson-Eluwa, V., Valentine, I. E., \& Keneth, O. (2019). Product Quality Perception and Customer Loyalty. Archives of Business Research, 7(3.2).

Rohwiyati, R., \& Praptiestrini, P. (2019). The Effect of Shopee e-Service Quality and Price Perception on Repurchase Intention: Customer Satisfaction as Mediation Variable. Indonesian Journal of Contemporary Management Research, 1(1), 4754.

Romdonny, J., \& Rosmadi, M. L. N. (2019). Factors Affecting Customer Loyalty in Products. Budapest International Research and Critics Institute (BIRCI-Journal): Humanities and Social Sciences, 2(1).

SiVARAM, M., Hudaya, A., \& Ali, H. (2019). BUILDING A PURCHASE AND PURCHASE DECISION: ANALYSIS OF BRAND AWARENESS AND BRAND LOYALTY. Dinasti International Journal of Education Management And Social Science, 1(2), 235-248.

Sugiyono. (2016). Metode Penelitian Bisnis. Alfabeta. Bandung.

Sugiyono. (2011). Metode Penelitian Pendidikan (Pendekatan Kuantitatif, Kualitatif dan $R \& D)$. Alfabeta. Bandung.

Sulistiorini, MS., Ali, H. (2017). Customer Satisfaction Model: Product Analysis, Price, Promotion and Distribution (Case Study At Pt Integrasia Utama). International Journal of Applied Business and Economic Research. the Investor Loyalty: The Investment Coordinating Board. International Journal of Business and Commerce.

Te Tu, Y., Wang, C. M., \& Chang, H. C. (2012). Corporate Brand Image and Customer Satisfaction on Loyalty: An Empirical Study of Starbucks Coffee in Taiwan. Taiwan. Journal of Social and Development Sciences, 3(1), 24-32.

Tjiptono, Fandy \& Gregorius Chandra (2011). Service, Quality \& Satisfaction. Edisi 3, Andi: Yogyakarta.

Tjiptono, Fandy (2014). Strategi pemasaran. Edisi 4. ANDI: Yogyakarta

Tjiptono, Fandy. (2008). Strategi pemasaran. Edisi 3. ANDI: Yogyakarta

Turuis, T. F. (2019). Analisis Faktor-Faktor Yang Mempengaruhi Loyalitas Nasabah Tabungan Bunaken Pada PT. Bank SulutGo Kantor Cabang Pembantu Ranotana. JURNAL RISET BISNIS DAN MANAJEMEN, 7(4).

Wantara, P., \& Tambrin, M. (2019). The Effect of Price and Product Quality Towards Customer Satisfaction and Customer Loyalty on Madura Batik. International Tourism and Hospitality Journal, 2(1), 1-9. 
Xie, Y. (2020). The relationship among marketing mix, customer satisfaction and customer loyalty of Chinese tourists to budget hotel of central Bangkok.

Yunita, D., Ali, H. (2017). Model of Purchasing Decision (Renting) of Generator Set: Analysis of Product Quality, Price an Service at PT. Hartekprima Listrindo. Scholars Journal of Economics, Business and Management, e-ISSN, 23485302. 